\title{
Growth biorhythms in the freshwater pearl mussel Margaritifera margaritifera (Bivalvia, Margaritiferidae). Livojoki river population (Karelia)
}

\author{
Alexey A. Zotin ${ }^{1}$, Svetlana A. Murzina ${ }^{2,{ }^{*}}$ and Evgeny P. Ieshko ${ }^{2}$ \\ ${ }^{1}$ Koltsov Institute of Developmental Biology of the Russian Academy of Sciences, 26 Vavilov St., 119334 Moscow, Russia \\ ${ }^{2}$ Institute of Biology of the Karelian Research Centre of the Russian Academy of Sciences, 11 Pushkinskaya St., 185910 Petrozavodsk, \\ Karelia
}

\begin{abstract}
Individual linear growth rates were studied in freshwater pearl mussels Margaritifera margaritifera from the Livojoki River. Growth deceleration coefficients were shown to vary widely and differ significantly among individuals. The average value of the growth deceleration coefficient for the population is 0.060 . The growth of mussels in the Livojoki River is accompanied by two regular biorhythms. These biorhythm periods were roughly constant both through an individual's ontogeny and among mussels, their average periods were 7.16 and 4.09 years. We discuss the possibility that these biorhythms are of thermodynamic nature.
\end{abstract}

Keywords: Margaritifera / Bivalvia / Karelia / growth / biorhythms

Résumé - Bioryhtmes de croissance chez la moule perlière d'eau douce Margaritifera margaritifera (Bivalvia, Margaritiferidae). Population de la rivière Livojoki (Carélie). Les taux de croissance linéaire individuels ont été étudiés chez les moules perlières d'eau douce Margaritifera margaritifera de la rivière Livojoki. Les coefficients de ralentissement de la croissance varient considérablement d'une moule à l'autre. La valeur moyenne du coefficient de ralentissement de la croissance pour la population est de 0,060 . La croissance des moules dans la rivière Livojoki s'accompagne de deux biorythmes réguliers. Ces périodes de biorythme étaient à peu près constantes, aussi bien dans l'ontogenèse d'un individu que parmi les moules, leurs périodes moyennes étaient de 7,16 et 4,09 ans. Nous discutons de la possibilité que ces biorythmes soient de nature thermodynamique.

Mots-clés : Margaritifera / Bivalve / Carélie / croissance / biorythmes

\section{Introduction}

The freshwater pearl mussel M. margaritifera L. is an endangered species in the aquatic fauna of European waters, included in the IUCN Red List (IUCN, 1996), the Red Data Book of the Russian Federation (Ziuganov and Zotin, 2001), and the Red Data Book of Karelia (Artemiev, 2007). It is currently believed that $95-100 \%$ of the living pearl mussel populations in Central and Southern Europe are on the brink of extinction (Popov, 2014; Sousa et al., 2015).

Sustainable, actively breeding populations have survived in less than 50 rivers in Canada, Scotland, north-west Russia, and north-east Scandinavia. Some scant pearl mussel colonies have survived in Bavaria, Czech Republic, and Austria

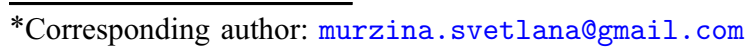

(Young et al., 2000). Judging by recent estimates of mussel numbers (Geist, 2005; Larsen et al., 2007), the key to conservation of this endangered species in the near future will belong to rivers of the White Sea and Barents Sea catchments.

One of the indicators for evaluating the state of $M$. margaritifera populations is the growth rate of the mussels. The growth rate of these mollusks is determined by the growth constant (Bauer, 1992), namely, the coefficient $k$ of the von Bertalanffy equation of growth: $L=L_{\infty}(1-\exp (-k t))$, where $L$ is length of mollusk at age $t$ and $L_{\infty}$ is asymptotic length of mollusk. Previous research has demonstrated that the growth constant in this species is strongly related to the latitude at which the mussels live, primarily in connection with the temperature conditions (Zotin and Ieshko, 2017). Other environmental factors, however, also appear to influence growth rates. This can be seen in the similarity of the growth constants for the southernmost populations of Western 
Europe (Spain) and southernmost populations of Karelia (R. Syskyanjoki, Lake Ladoga catchment), in spite of the difference in latitudes (Zotin and Ieshko, 2017).

Studying growth parameters in various freshwater pearl mussel populations is of great importance, since the growth rate of the mussels is inversely related to their life span (Bauer, 1992). The life-shortening effect of a higher growth rate results in a reduction of generation numbers and, hence, a decrease in offspring of the mussels. This is particularly important since $M$. margaritifera populations reproduce only once per year. Maturation in the southernmost populations in Portugal was determined to occur in year 6 (Varandas et al., 2013), 6 years earlier than in northern populations (Ziuganov et al., 1994); however, the life expectancy is reduced by at least 20 years. This means that the number of generations in southern populations is significantly lower than that of northern populations. The fecundity of pearl mussels depends on the length of the mollusk (Ziuganov et al., 1994). The maximal length of pearl mussels in southern populations is shorter in comparison to mussels in northern populations, thus, the fecundity is also lower. Coincidentally, the first recorded extinction of pearl mussels was observed in the southernmost populations of Europe. In Western Europe, the populations in Spain (Morales and Lizana, 2014), Portugal (Sousa et al., 2015), and Austria (Young et al., 2000) are on the brink of extinction. In Eastern Europe, populations are disappearing in Poland (Dyduch-Falniowska and Zając, 2005), Latvia (Rudzīte et al., 2015), and Russia (Leningrad and Novgorod district) (Popov and Ostrovsky, 2013). The survival of pearl mussels is, however, also influenced by other factors: water pollution, pearl fishing, dam building, eutrophication, and many others (Araujo and Ramos, 2001). All these factors must be taken into account when planning and implementing measures for species conservation.

A further threat to pearl mussels is the rising of ambient temperatures, which causes the population to lose sustainability and decline to the point of extinction. This, in turn, can lead to the transformation of the entire ecosystem, since the filtering activity of the mussels significantly influences water quality.

Another process associated with mollusk growth is biorhythms (Zotin, 2009). Previous studies have established that rhythmic processes play a significant role in the performance of living systems. Biorhythms are associated with homeostasis, homeoresistance, adaptation, growth, and metabolism. The identification of biorhythms, the determination of their parameters, and the effect of various external factors on these parameters will undoubtedly lead to new knowledge of the processes both for individual development and in the evolution of ecosystems and biocenoses. The parameters of these biorhythms are determined through evolution by selecting the optimal values for the existence of certain populations and species.

Any changes that take place within an organism can be divided into two types: rhythms associated with periodic fluctuations of environmental factors (exogenous, directly caused by environmental factors, and endogenous, the periods that coincide with the period of oscillations of some external process) and endogenous periodic processes with no relation to the external environment.
The first type of biorhythm is circadian fluctuations and seasonal (annual) changes, lasting for a period of about 1 year. These fluctuations and changes that influence the growth of almost all species of animal taxa have been well documented (Goodwin, 1963; Mina and Klevezal', 1976; Shmidt-Nielsen, 1997; Klevezal', 2007).

However, endogenous periodic processes, with no relation to the external environment, have been studied only fragmentarily. The most well-known growth rhythms are associated with moulting in arthropods and a number of other animals (Mina and Klevezal', 1976). Vertebrates have rhythms of growth over a period of about 2 weeks (Kopeč, 1937; Fedorov, 1973; Sipachov, 1970; Zadornova and Arsent'eva, 2011). Periodic fluctuations in growth rate within an 11-year period are described in a number of long-lived bivalves (Glycymeris yessoensis, Macoma middendorffi, Venericardia crebricostata, and Crenomytilus grayanus) (Zolotarev, 1974a,b).

Daily measurements in many animal species revealed growth biorhythms during a period of about 2 weeks (Sipachov, 1970). For periods of time comparable to the respective life expectancy, two biorhythms of specific growth rates are described, one of which we associate with the current stationary state of the living system, and the second, with the final stationary state, to which an organism aspires throughout life (Zotin and Zotin, 1996, 1997).

Singular spectral analysis, which is currently the most highly developed method was applied to determine the wave components from the overall time dependence of the change in one or another parameter (Kryanev and Lukin, 2010).

This particular method has previously been used to detect three endogenous growth biorhythms of the large pond snail Lymnaea stagnalis (Zotin and Kleimenov, 2013).

However, the detection of biorhythms of growth is accompanied by certain difficulties: long periods of ontogenesis will need to be studied with a high frequency of measurements. This way it is possible to detect biorhythms reliably. The period between each respective measurement must be at least three times shorter than the duration of the biorhythm. One species from which it is possible to obtain data to detect and characterize growth biorhythms is the freshwater bivalve mollusk $M$. margaritifera. Representatives of this species often live more than 10 years and the presence of annual rings on the surface of their shells makes it possible to study their growth with a frequency of one measurement per year.

The main hypothesis tested in this research was whether there are endogenous growth biorhythms in the freshwater pearl mussel $M$. margaritifera by analyzing a population inhabiting the Livojoki River.

\section{Material and methods}

The shells of dead freshwater pearl mussels $M$. margaritifera $L$. were collected from the channel and on the banks of the Livojoki River (Kem' River catchment, Karelia). The top conchiolin layer was removed by boiling the shells in $1 \mathrm{M} \mathrm{KOH}$ solution for $10 \mathrm{~min}$. This procedure makes the annual growth rings formed in the middle prismatic layer visible. Shell images were taken by scanning them with a scanner (HP ScanJet 5400c, China). The length of each intact 
annual ring was measured using Microsoft Excel software at $0.1 \mathrm{~mm}$ precision.

The general growth equation was applied using a modified version of the von Bertalanffy equation (Zotin, 2015):

$$
\mathrm{d} L_{t} / L_{t} \mathrm{~d} t=V_{0}(1-a)^{t},
$$

where $L_{t}$ is the annual ring length at age $t, V_{0}$ is the initial growth rate, and $a$ is the coefficient defining growth deceleration.

The data were approximated by the recurrent form of equation (1):

$$
L=-a L_{t}+d
$$

where $\Delta L$ is the shell length increment in the year following age $t, d=-V_{0} / \ln (1-a)+L_{0}\left(L_{0}\right.$ is the shell size at age $\left.t=0\right)$.

The coefficients of equation (2) were compared by regression analysis. The applicability of this equation was tested by nonlinear criteria (Zotin, 2000).

The age of mussels $(t)$ was calculated by summing up the age of the first measured annual growth ring $\left(t_{1}\right)$ and the number of annual rings discernible on the shell surface. The age of the first measured annual growth ring was calculated using the analytical form of equation (1):

$$
t_{1}=\log _{(1-a)}\left(1-a L_{1} / d\right),
$$

where $L_{1}$ is the length of the first measured annual growth ring. This technique had to be applied since the apical area of the shell was corroded in the vast majority of the mussels and a part of the annual rings was undetectable.

The error rate of determining the age using this method is no higher than 5\% (Ziuganov et al., 1994). Subsequently, in the analysis of the studied population of mollusks, the error in determining the age of the oldest animals is no more than 2 years. This margin of error was deemed acceptable for the calculations.

The resulting data were smoothed by cubic splines. The time series of the dependence of the relative growth rate $(\mathrm{d} L / L \mathrm{~d} t)$ on annual ring age was calculated using MATLAB software (version 7.3.0.267, The MathWorks, Inc, USA).

Biorhythms were detected by singular spectrum analysis using Caterpillar-SSA software (version 3.40, by GistaT Group, Russia). The application was run in the "not centered" mode. The option "caterpillar length" ("window length") was chosen as follows: the window length was varied from four to one half of the measured annual rings rounded to the nearest integer, and the variant for which the main trend and rhythms were the most clear was chosen. Rhythms with a period below 3 years were regarded as "stochastic noise.". The biorhythm period $(P)$ was determined by calculating the mean of the doubled time intervals between successive local extreme points. The biorhythm amplitude $(A)$ was calculated as one half of the difference between the values of successive local extreme points.

The statistical distributions that are composed of the mean values of the parameters calculated for individual mussels were compared against the normal distribution using the Shapiro-Wilk test (Shapiro and Wilk, 1965).

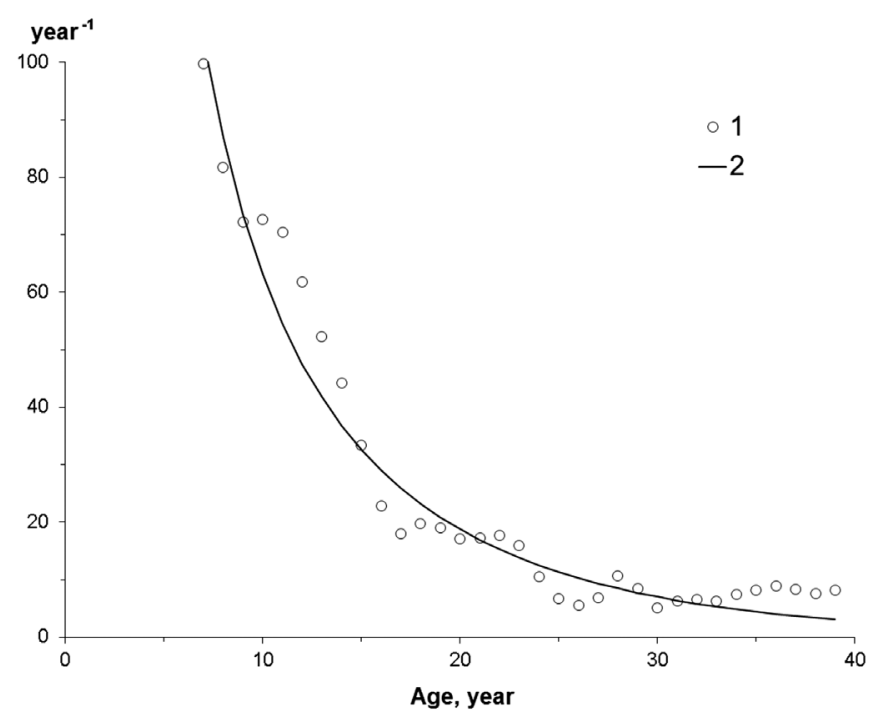

Fig. 1. An example of age-related change in relative growth rate $(\mathrm{d} L / L \mathrm{~d} t)$ in $M$. margaritifera (Specimen No. 9). 1-experimental data; 2 -approximation by equation (1). The ordinate is the relative growth rate.

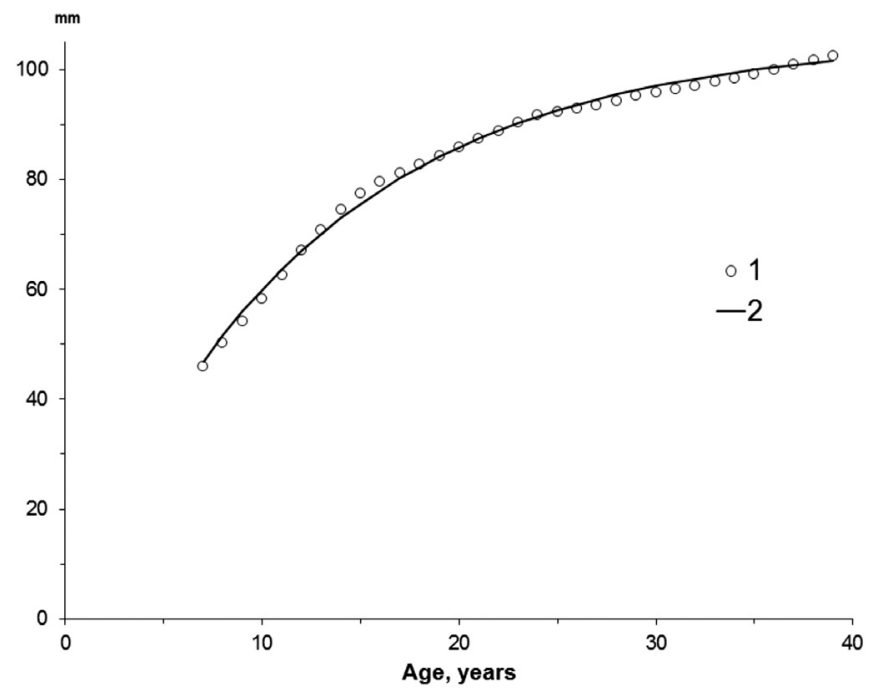

Fig. 2. An example of age-related change in annual growth rings in M. margaritifera (specimen No. 9). 1-length of annual growth rings; 2-approximation by equation (1).

\section{Results}

The main linear growth trend in individual $M$. margaritifera specimens is closely modeled by equation (1). An example of data approximation by means of this equation is shown in Figure 1. An example of age-related change in annual growth rings in M. margaritifera are presented in Figure 2. The value of coefficients in the equation, the morphometric parameters (length, height, and convexity), and the age of the mussels are shown in Table 1.

Coefficients $a$ in equation (2), which specify growth deceleration, vary widely among individuals within each 
A.A. Zotin et al.: Knowl. Manag. Aquat. Ecosyst. 2018, 419, 44

Table 1. Individual size, age, and growth characteristics of M. margaritifera from the Livojoki River.

\begin{tabular}{|c|c|c|c|c|c|}
\hline Specimen No. & $n$ & $L(\mathrm{~mm})$ & $T$ (years) & $a$ (per year) & $d$ (mm/year) \\
\hline 1 & 16 & 96.6 & 24 & $0.059 \pm 0.011$ & $7.5 \pm 0.8$ \\
\hline 2 & 26 & 104.1 & 33 & $0.086 \pm 0.007$ & $9.5 \pm 0.5$ \\
\hline 3 & 19 & 87.4 & 23 & $0.093 \pm 0.012$ & $9.0 \pm 0.8$ \\
\hline 4 & 26 & 103.3 & 35 & $0.050 \pm 0.007$ & $6.2 \pm 0.6$ \\
\hline 5 & 19 & 87.2 & 25 & $0.091 \pm 0.007$ & $8.7 \pm 0.4$ \\
\hline 6 & 28 & 115.3 & 35 & $0.059 \pm 0.006$ & $7.7 \pm 0.5$ \\
\hline 7 & 30 & 108.7 & 43 & $0.047 \pm 0.005$ & $5.9 \pm 0.4$ \\
\hline 8 & 21 & 108.3 & 28 & $0.074 \pm 0.008$ & $9.1 \pm 0.7$ \\
\hline 9 & 33 & 103.4 & 40 & $0.082 \pm 0.006$ & $8.7 \pm 0.5$ \\
\hline 10 & 22 & 100.5 & 30 & $0.031 \pm 0.009$ & $5.1 \pm 0.7$ \\
\hline 11 & 28 & 111.8 & 36 & $0.038 \pm 0.006$ & $5.6 \pm 0.5$ \\
\hline 12 & 26 & 101.0 & 37 & $0.058 \pm 0.007$ & $6.6 \pm 0.6$ \\
\hline 13 & 21 & 100.0 & 27 & $0.050 \pm 0.007$ & $6.7 \pm 0.5$ \\
\hline 14 & 25 & 112.2 & 34 & $0.062 \pm 0.008$ & $7.9 \pm 0.7$ \\
\hline 15 & 25 & 101.5 & 33 & $0.063 \pm 0.006$ & $7.2 \pm 0.5$ \\
\hline 16 & 24 & 99.1 & 31 & $0.060 \pm 0.011$ & $7.0 \pm 0.8$ \\
\hline 17 & 24 & 105.1 & 33 & $0.085 \pm 0.009$ & $9.5 \pm 0.7$ \\
\hline 18 & 23 & 110.1 & 32 & $0.064 \pm 0.009$ & $8.0 \pm 0.7$ \\
\hline 19 & 24 & 110.0 & 31 & $0.036 \pm 0.007$ & $5.8 \pm 0.6$ \\
\hline 20 & 26 & 107.3 & 35 & $0.049 \pm 0.007$ & $6.3 \pm 0.6$ \\
\hline 21 & 31 & 108.0 & 39 & $0.049 \pm 0.004$ & $6.1 \pm 0.4$ \\
\hline 22 & 24 & 104.0 & 31 & $0.052 \pm 0.005$ & $6.7 \pm 0.4$ \\
\hline 23 & 21 & 97.5 & 28 & $0.045 \pm 0.009$ & $6.0 \pm 0.6$ \\
\hline 24 & 22 & 102.0 & 29 & $0.052 \pm 0.008$ & $6.7 \pm 0.6$ \\
\hline 25 & 18 & 87.5 & 24 & $0.058 \pm 0.011$ & $6.7 \pm 0.7$ \\
\hline 26 & 15 & 77.3 & 20 & $0.047 \pm 0.009$ & $6.0 \pm 0.5$ \\
\hline 27 & 9 & 64.2 & 12 & $0.07 \pm 0.046$ & $7.9 \pm 2.0$ \\
\hline 28 & 8 & 65.1 & 9 & $0.104 \pm 0.029$ & $10.5 \pm 1.3$ \\
\hline 29 & 7 & 50.5 & 10 & $-0.019 \pm 0.049$ & $4.5 \pm 1.4$ \\
\hline 30 & 6 & 50.1 & 9 & $0.036 \pm 0.064$ & $6.5 \pm 2.1$ \\
\hline 31 & 6 & 36.8 & 8 & $0.177 \pm 0.063$ & $8.5 \pm 1.6$ \\
\hline 32 & 5 & 32.0 & 6 & $0.024 \pm 0.169$ & $4.8 \pm 3.3$ \\
\hline
\end{tabular}

$n$ is the number of measured annual growth rings, $L$ is the length, $T$ is the individual age, and $a$ and $d$ are coefficients of the growth in equation (2).

habitat and differ significantly from one another $(p<0.001)$. The variation series composed of the values of equation (2) coefficients are, however, normally distributed according to the Shapiro-Wilk test. For the Livojoki River population in general, the results were $a=0.060 \pm 0.006$ and $d=7.2 \pm 0.3 \mathrm{~mm} /$ year. These values can be used to characterize the Livojoki population in interpopulation and interspecies studies.

Singular spectrum analysis shows that the main trends of change in shell size practically coincide with the curve drawn after approximation by growth equation (1) for all the individuals in the surveys.

The analysis of the kinetics of relative growth rate in individual development in $M$. margaritifera revealed the existence of biorhythms accompanying the main trend (Fig. 1).

The biorhythms are highlighted after the extraction of wave components by singular spectrum analysis (Fig. 3). We performed this analysis only on mussels with at least 15 measured annual growth rings. The sample set consisted of 26 mussels.

All individuals were found to have followed two regular biorhythms with different frequencies of oscillation (Tab. 2;
Fig. 3). No significant variation in the period of the biorhythms was detected, neither through the lifetime of individuals nor among individuals. The average period of oscillations within the entire sample set is $7.16 \pm 0.27$ years for low-frequency and $4.09 \pm 0.07$ years for high-frequency biorhythms.

The amplitude of the biorhythms varies widely from an average of $3.7 \pm 0.5$ per year for low-frequency and $2.2 \pm$ 0.2 years $^{-1}$ for high-frequency biorhythms.

An important observation is that the increment of the growth constant and initial growth rate values in the north to south direction are higher in the north-west of European Russia than in Western Europe (Zotin and Ieshko, 2017), proving that temperature is not the only environmental parameter influencing growth rate.

\section{Discussion}

The measure commonly used to describe growth in bivalves is the so-called growth constant $(k)$, derived from the von Bertalanffy equation (Alimov, 1981; Bauer, 1992; Ziuganov et al., 1994). We prefer using another constant 
A.A. Zotin et al.: Knowl. Manag. Aquat. Ecosyst. 2018, 419, 44

Table 2. Characteristics of the biorhythms of the relative linear growth rate in M. margaritifera.

\begin{tabular}{|c|c|c|c|c|c|c|c|c|c|}
\hline Specimen No. & $m_{1}$ & $P_{1}$, years & $m_{2}$ & $P_{2}$ (years) & No. specimen & $m_{1}$ & $P_{1}$ (years) & $m_{2}$ & $P_{2}$ (years) \\
\hline 1 & 3 & 8.0 & 7 & $4.3 \pm 0.3$ & 14 & 6 & $7.6 \pm 0.7$ & 13 & $3.7 \pm 0.3$ \\
\hline 2 & 6 & $6.8 \pm 1.0$ & 12 & $4.0 \pm 0.3$ & 15 & 5 & $8.5 \pm 1.3$ & 10 & $4.4 \pm 0.4$ \\
\hline 3 & 4 & $7.3 \pm 1.8$ & 9 & $4.0 \pm 0.9$ & 16 & 8 & $4.9 \pm 0.4$ & 10 & $4.4 \pm 0.6$ \\
\hline 4 & 6 & $7.6 \pm 1.5$ & 11 & $4.2 \pm 0.4$ & 17 & 8 & $5.4 \pm 1.8$ & 12 & $3.5 \pm 0.3$ \\
\hline 5 & 5 & $8.0 \pm 2.0$ & 8 & $4.3 \pm 0.3$ & 18 & 5 & $8.0 \pm 1.8$ & 9 & $4.3 \pm 0.3$ \\
\hline 6 & 8 & $7.4 \pm 1.4$ & 13 & $4.2 \pm 0.3$ & 19 & 6 & $6.4 \pm 2.6$ & 9 & $4.8 \pm 0.4$ \\
\hline 7 & 8 & $7.7 \pm 1.3$ & 11 & $4.8 \pm 0.4$ & 20 & 7 & $6.3 \pm 1.3$ & 11 & $4.4 \pm 0.4$ \\
\hline 8 & 5 & $7.5 \pm 2.9$ & 8 & $4.0 \pm 0.4$ & 21 & 11 & $4.8 \pm 0.4$ & 16 & $3.6 \pm 0.3$ \\
\hline 9 & 8 & $8.0 \pm 0.6$ & 15 & $4.0 \pm 0.3$ & 22 & 7 & $6.0 \pm 0.5$ & 12 & $3.6 \pm 0.2$ \\
\hline 10 & 4 & $7.3 \pm 2.7$ & 10 & $4.0 \pm 0.3$ & 23 & 5 & $7.0 \pm 0.6$ & 10 & $3.6 \pm 0.3$ \\
\hline 11 & 10 & $5.3 \pm 0.7$ & 14 & $3.5 \pm 0.2$ & 24 & 5 & $7.0 \pm 1.7$ & 10 & $4.0 \pm 0.5$ \\
\hline 12 & 5 & $8.5 \pm 1.5$ & 9 & $4.5 \pm 0.5$ & 25 & 6 & $4.8 \pm 1.0$ & 8 & $3.7 \pm 0.3$ \\
\hline 13 & 4 & $10.0 \pm 1.2$ & 10 & 4.0 & 26 & 3 & 10.0 & 5 & $4.5 \pm 1.3$ \\
\hline
\end{tabular}

$m$ is the number of local extreme points, $P$ is the biorhythm period, index 1 is the low-frequency biorhythm, and index 2 is the high-frequency biorhythm. Data are given for the shells with at least 15 measured annual growth rings.

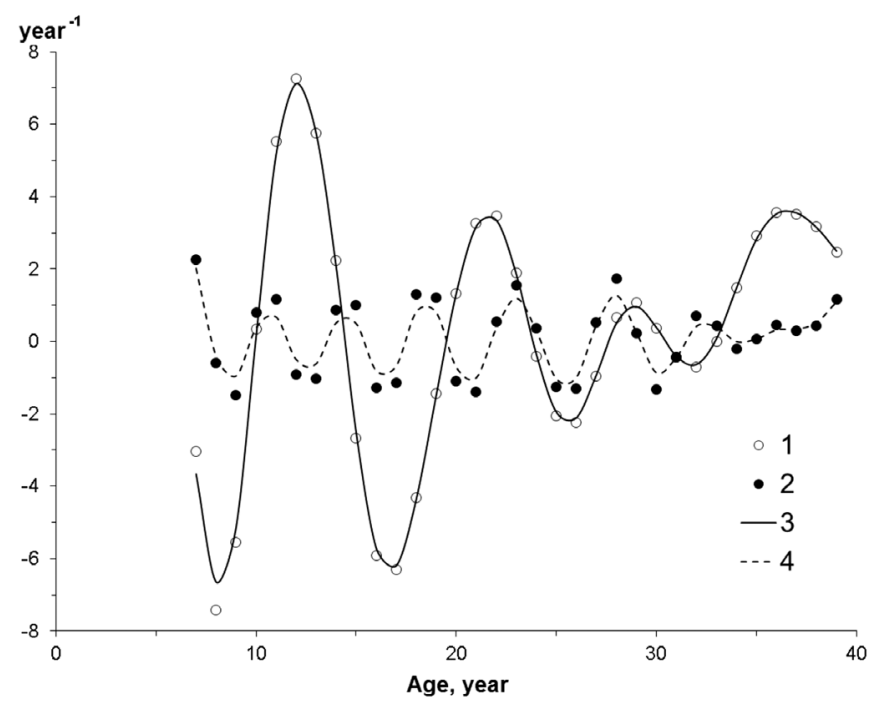

Fig. 3. An example of relative growth rate biorhythms $(\mathrm{d} L / L \mathrm{dt})$ in M. margaritifera (specimen No. 9). Biorhythms: 1-low frequency; 2-high frequency. Fitting by cubic splines: 3-low-frequency biorhythm; 4-high-frequency biorhythm.

instead, which we have termed the growth deceleration constant $(a)$, and which is related to the growth constant as $a=1-\exp (-k)$. Here, if $k$ is near zero, then the coefficients $a$ and $k$ are roughly equal. The advantages of using the coefficient $a$ instead of the growth constant $k$ are that this coefficient is distributed normally, it is included in the recurrent form of equation (2) as a regression coefficient and, hence, it is suitable for comparisons based on standard regression analysis techniques.

The average growth deceleration constant for the mussels surveyed was $a=0.060$, whereas the growth constant $k$ was measured at $k=0.062$. According to the literature, the growth constant $k$ can vary among populations within a range of 0.02-0.11 (Alimov, 1981; Bauer, 1992; Ziuganov et al., 1994;

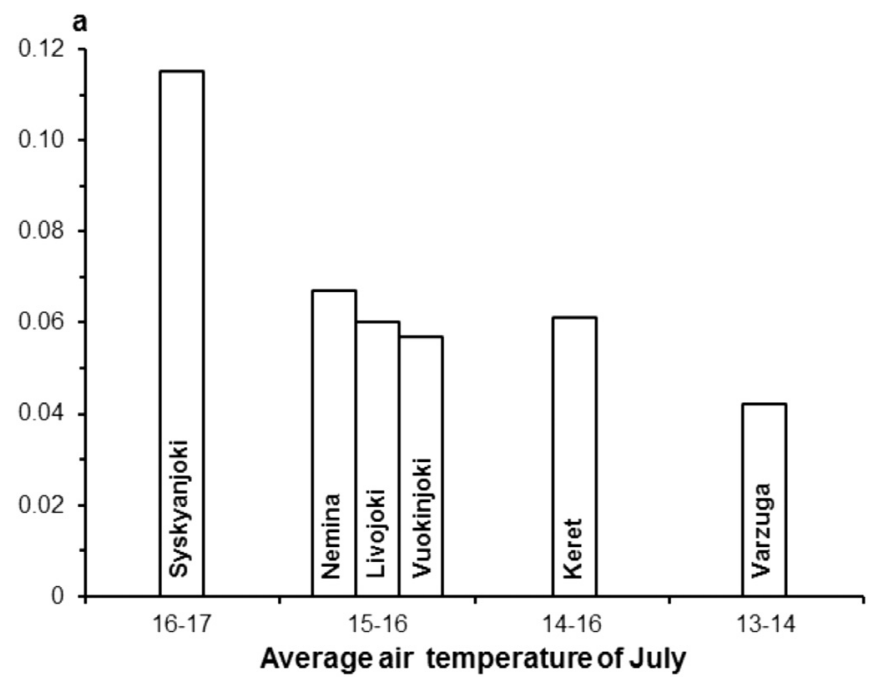

Fig. 4. Correlation of the coefficient of growth deceleration and the average air temperature in mollusk habitats in July (the data on the coefficient of growth deceleration is taken from Zotin, Ieshko, 2017; the data on temperature is taken from Gardarika (2018). http://kareliagardarika.ru/gallery/card-of-karelia/).

Hastie et al., 2000; San Miguel et al., 2004; Dunca et al., 2011; Zotin and Ieshko, 2017). The value of the growth constant for the Livojoki population is thus close to the average for M. margaritifera.

The differences in growth deceleration coefficients $a$ from equations (1) and (2) among individuals in the M. margaritifera population are probably due to habitat conditions, specifically ambient temperature. The correlation of the coefficient $a$ and temperature of place of habit is presented in Figure 4.

One of the possible indicators of the water temperature regime is the habitat latitude. The growth constant has been shown to be inversely related to this parameter (Bauer, 1992; Zotin and Ieshko, 2017). Our data in this study confirm these conclusions (Tab. 3). 
Table 3. A comparison of growth parameters in different M. margaritifera populations (results on populations from the Syskyanjoki River, the Nemina River and the Varzuga River presented in Zotin and Ieshko (2018)).

\begin{tabular}{lllll}
\hline $\begin{array}{l}\text { River } \\
\text { (latitude) }\end{array}$ & $a$ & $k$ (per year) & $P_{1}$ (years) & $P_{2}($ years) \\
\hline $\begin{array}{l}\text { Syskyanjoki } \\
\left(61.7^{\circ} \mathrm{N}\right)\end{array}$ & $\begin{array}{l}0.114 \pm 0.003 \\
(n=88)\end{array}$ & 0.121 & - & $3.9 \pm 0.1$ \\
Nemina & $0.064 \pm 0.005$ & 0.066 & $5.1 \pm 0.1$ & $(n=87)$ \\
$\left(62.8^{\circ} \mathrm{N}\right)$ & $(n=23)$ & & $(n=13)$ & $3.9 \pm 0.1$ \\
Livojoki & $0.060 \pm 0.006$ & 0.062 & $7.2 \pm 0.3$ & $(n=20)$ \\
$\left(64.8^{\circ} \mathrm{N}\right)$ & $(n=32)$ & 0.049 & $6.5 \pm 0.1$ & $(n=26)$ \\
Varzuga & $0.048 \pm 0.001$ & & $(n=68)$ & $4.1 \pm 0.1$ \\
$\left(66.7^{\circ} \mathrm{N}\right)$ & $(n=90)$ & & $(n=68)$ \\
\hline
\end{tabular}

$a$ is the growth deceleration coefficient in equation (1), $k$ is the growth constant, $n$ is the number of specimens, $P_{1}$ is the period of low-frequency biorhythms, $P_{2}$ is the period of high-frequency biorhythms, and "-_" is the no biorhythm detected.

An acceleration of growth shortens the life span in mussels (Bauer, 1992) and this, in turn, leads to a decrease in fecundity/ reproduction rate of the mussels due to a reduced number of generations. As a result, the southernmost populations barely reproduce. Any change in environmental conditions may push these populations toward extinction, as has happened before to many populations in the Leningrad and Novgorod regions (Popov, 2014). This indicates that habitats in the Livojoki River are still far from having conditions that pose a threat to $M$. margaritifera. Yet, considering global warming, monitoring of this population should be continued.

The comparative interpopulation study of biological growth rhythms has just begun. The data gathered so far can therefore provide only preliminary results.

A comparison of the biorhythms of the relative linear growth rate in the $M$. margaritifera population of the Livojoki River with other populations revealed a similar duration of high-frequency biorhythms. The periods of lowfrequency biorhythms vary among populations, and no such biorhythms were detected in mussels from the Syskyanjoki population (Tab. 3). A possible explanation is that the two biorhythms have similar periods in the Syskyanjoki population and thus disguise each other (unpublished). The similarity in the periods of high-frequency rhythms suggests that they are controlled by genetic features of the species in general, and independent of environmental parameters. For low-frequency biorhythms on the other hand, environmental factors appear to be of key significance. There is no clear explanation for the variation in the periods of low-frequency biorhythms so far. It could be due to both the genetic characteristics of the mussels and the environmental conditions in their habitats. The period of low-frequency biorhythms in the Livojoki population is the longest among all the studied populations (Tab. 3). Given that River Livojoki is situated in the optimal part of the freshwater pearl mussel distribution range, in the north-west of European Russia, it is quite probable that the period of low-frequency biorhythms is an indicator of the optimal of habitat conditions for the mussels. The higher this value is, the more favorable are the environmental conditions for $M$. margaritifera.

Growth biorhythms are not unique to $M$. margaritifera. They have been detected in various gastropod species and animals of other taxa (Sipachov, 1970; Zotin, 2009; Zotin and Kleimenov, 2013). These biorhythms can be associated with purely biological phenomena. They can, for instance, result from the organism's response to periodic processes in the environment of which we are unaware.

Another hypothesis that can be derived from the assumptions of modern thermodynamics claims that a characteristic trait of nonlinear dissipative structures, including living systems, is the existence of stationary states (Zotin, 2009). In this case, the tendency toward a stationary state is accompanied by a rhythm with a certain characteristic time (Nicolis, 1972; Prigogine, 1972; Nicolis and Prigogine, 1977; Malek-Mansour et al., 1980). It is quite possible that the biorhythms identified in the relative linear growth rate are of thermodynamic nature.

Acknowledgments. The study was funded by the Presidium of the Russian Academy of Sciences (under the programme "Biodiversity of Living Systems"), by the state budgetary themes No. 0221-2017-0042 and No. 0221-2017-50.

Conflict of interest. The authors declare no conflict of interest.

\section{References}

Alimov AF. 1981. Functional Ecology of Freshwater Bivalves. Nauka: Leningrad, 248 p. (in Russian).

Araujo R, Ramos A. 2001. Action Plans for Margaritifera auricularia and Margaritifera margaritifera in Europe. Strassbourg: Council of Europe.

Artemiev AV. 2007. Red Data Book of Karelia, Petrozavodskij Gos. Univ, Petrozavodsk, 364 p. (in Russian).

Bauer G. 1992. Variation in life span and size of the freshwater pearl mussel. J Anim Ecol 61: 425-436.

Dunca E, Söderberg H, Norrgrann O. 2011. Shell growth and age determination in the freshwater pearl mussel Margaritifera margaritifera in Sweden: natural versus limed streams. Ferrantia 64: 48-58.

Dyduch-Falniowska A, Zając K. 2005. Margaritifera margaritifera (LINNEAUS, 1758) eastern pearlshell: freshwater pearl mussel. Polska czerwona księga zwierzqt. bezkręgowce. 1: s. 447. 
Fedorov VI. 1973. Growth, Development and Productivity of Animals. Moscow: Kolos (in Russian).

Geist J. 2005. Conservation genetics and ecology of European freshwater pearl mussels (Margaritifera margaritifera L.). Ph.D. thesis, Technical University of Munich, München, Germany, 121 p.

Goodwin BC. 1963. Temporal Organization in Cells. London: Academic Press.

Hastie LC, Young MR, Boon PJ. 2000. Growth characteristics of freshwater pearl mussels, Margaritifera margaritifera (L.). Freshw Biol 43: 243-256.

Klevezal' GA. 2007. Principles and Methods of Determining the Age of Mammals. Moscow: KMK.

Kopeč S. 1937. Studia nad przebiegiem i natura normalnych waha w ciezarze ciala myszy. I. Obras dimorfismu pliciowego w przebiegy Wahan, Spraw. Pos. Tow. Nauk. Warsz. Wydz. IV. Biol. 30: 222-238.

Kryanev AV, Lukin GV. 2010. Metric Analysis and Data Processing. Moscow: Fizmatlit (in Russian).

Larsen BM, Eken M, Tysse Å, Engen Ø. 2007. Overvåking av elvemusling i Simoa, Buskerud. Statusrapport, NINA Rapport, Trondheim, $45 \mathrm{p}$.

Malek-Mansour M, Nicolis G, Prigogine I. 1980. Nonequilibrium phase transitions in chemical systems. Termodinamika i kinetika biologicheskih processov. Moscow: Nauka, pp. 59-83 (in Russian).

Mina MV, Klevezal' GA. 1976. Growth of Animals. Moscow: Nauka (in Russian).

Morales J, Lizana M. 2014. Negative climate change effects accelerate the extinction of the main population of pearl mussel Margaritifera margaritifera L., 1758 in the Duero Basin. Munibe (Ciencias Naturales-Natur Zientziak) No. 62: 103-127.

Nicolis G. 1972. Fluctuations around non-equilibrium states in open non-linear systems. J Stat Phys 6: 195-222.

Nicolis G, Prigogine I. 1977. Self-Organization in Nonequilibrium Systems: From Dissipative Structures to Order through Fluctuations. New York: Wiley Interscience, $512 \mathrm{p}$.

Popov I Yu. 2014. "Rule of the lake" and other patterns in the distribution of freshwater pearl mussel Margaritifera margaritifera Trudy KarNC RAS 2: 126-139.

Popov I Yu, Ostrovsky AN. 2013. Survival and extinction of the southern populations of freshwater pearl mussel Margaritifera margaritifera in Russia (Leningradskaya and Novgorodskaya oblast). Hydrobiologia 735: 161-177.

Prigogine I. 1972. La thermodynamique de la vie. La Recherche 24: $547-562$.

Red List of Threatened Animals. Gland, Switzerland: IUCN, 1996, $452 \mathrm{p}$.

Rudzīte M, Rudzītis M, Birzaks J, Poppels A, Onkele A. 2015. The freshwater pearl mussel Margaritifera margaritifera (Linnaeus 1758) in Latvia: assessment of the survival possivikities. Schr Malakool 28: 17-36.

San Miguel E, Monserrat S, Fernández C, Amaro R, Hermida M, Ondina P, Altaba CR. 2004. Growth models and longevity of freshwater pearl mussels (Margaritifera margaritifera) in Spain. Can J Zool 82: 1370-1379.
Shapiro SS, Wilk MB. 1965. An analysis of variance test for normality. Biometrika 52: 591-611.

Shmidt-Nielsen K. 1997. Animal Physiology: Adaptation and Environment. Cambridge: Cambridge Academy.

Sipachov SG. 1970. Rhythmic growth of animals, TGPI, Tyumen, 351 p. (in Russian).

Sousa R, Amorim Â, Froufe E, Varandas C, Teixeira A, Lopes-Lima M. 2015. Conservation status of the freshwater pearl mussel Margaritifera margaritifera in Portugal. Limnologica 50: 4-10.

Varandas S, Lopes-Lima M, Teixeira A, Hinzmann M, Reis J, Cortes R, Machado J, Sousa R. 2013. Ecology of southern European pearl mussels (Margaritifera margaritifera): first record of two new populations on the rivers Terva and Beça (Portugal). Aquat Conserv Marine Freshw Ecosyst. doi: 10.1002/aqc.2321

Young MR, Cosgrove PJ, Hastie LC. 2000. The extent of, and causes for, the decline of a highly threatened naiad: Margaritifera margaritifera. In: Bauer G, Wachtler $\mathrm{K}$, eds. Ecology and Evolutionary Biology of the Freshwater Mussels Unionoidea, Ecological Studies, Vol. 145. Berlin: Springer.

Zadornova NN, Arsent'eva NV. 2011. The manifestation of the rhythm of growth in birds. Mater Resp Nauch Prakt Konf "Nauka v razvitii sela", Cheboksary. http://agrotext.ru/379.html (in Russian).

Ziuganov VV, Zotin AA. 2001. European pearl mussel Margaritifera margaritifera (Linnaeus, 1758). Red Data Book of Russian Federation: Animals. Moscow: Astrel, pp. 61-62 (in Russian).

Ziuganov V, Zotin A, Nezlin L, Tretiakov V. 1994. The Freshwater Pearl Mussels and Their Relationships with Salmonid Fish. Moscow: VNIRO Publ. House, 104 p.

Zolotarev VN. 1974a. Multiannual rhythms of growth of marine bivalves. Biology of Marine Mollusks and Echinoderms. Proc. Sov. Jap. Symp. Marine Biol. Vladivostok: Izd. DVO AN SSSR, pp. $55-57$.

Zolotarev VN. 1974b. Multiannual rhythms of growth of mussel L. grayana shell. Ekologiya 3: 76-80.

Zotin AA. 2000. Statistical estimation of allometric coefficients. Biol Bull 27: 431-437.

Zotin AA. 2009. Patterns of growth and energy metabolism in the ontogeny of molluscs. PhD thesis, IDB RAS, Moscow (in Russian).

Zotin AA. 2015. The united equation of animal growth. Am J Life Sci 3: 345-351.

Zotin AA, Ieshko EP. 2017. Comparative analysis of the growth of Margaritifera margaritifera (Bivalvia) from different populations of Karelia and Kola Peninsula. Biol Bull 44: 1-5.

Zotin AA, Ieshko EP. 2018. Biorhythms of Margaritifera margaritifera (Bivalvia, Margaritiferidae) freshwater pearl mussel growth: population of Syuskyuyanioki River (Karelia). Russ J Dev Biol 49: 206-213.

Zotin AA, Zotin AI. 1996. Thermodynamic bases of developmental processes. J Non-Equilib Thermodyn 21: 307-320.

Zotin AA, Zotin AI. 1997. Phenomenological theory of ontogenesis. Int J Dev Biol 41: 917-921.

Zotin AA, Kleimenov S Yu. 2013. Endogenous biorhythms of the specific growth rate in individual development of Lymnaea stagnalis (Lymnaeidae, Gastropoda). Biol Bull 40: 1-10.

Cite this article as: Zotin AA, Murzina SA, Ieshko EP. 2018. Growth biorhythms in the freshwater pearl mussel Margaritifera margaritifera (Bivalvia, Margaritiferidae). Livojoki river population (Karelia). Knowl. Manag. Aquat. Ecosyst., 419, 44. 